\title{
Landscape evaluation on a regional level for sustainable tourism development
}

\author{
I. Jurinčič \\ Faculty of Tourism Studies Portorož Turistica, University of Primorska, \\ Slovenia
}

\begin{abstract}
Evaluation of tourism resources plays a vital role in the spatial planning of sustainable tourism. This article introduces an example of landscape evaluation on a regional level by means of a geographical information system. A Mediterranean landscape, Slovenska Istra, is the most developed tourist destination in Slovenia, which is why it needs a special approach in sustainable handling of the vast tourism resources it offers. The analysis of local factors in view of perspective tourism products showed that prudent handling of coastline tourism resources is particularly important, while inland parts of the coastline present an unexploited touristic potential.

Keywords: tourism resources, landscape evaluation, location factors, tourism spatial planning, tourism destination management, tourism products, geographic information system.
\end{abstract}

\section{Introduction}

A suitable evaluation of tourism resources plays a vital role in the planning of sustainable tourism. It enables an optimal exploit of tourism resources at disposal with minimum negative impacts on the natural, social and economic environment, which is the primary objective of sustainable tourism development. The evaluation of tourism resources displays comparative benefits of different tourism products in a certain destination; in our case the Slovenska Istra region.

Concerning the evaluation of different regions for tourism, various attempts have been made in different fields and with different procedures, contributing many new insights in this field. Countries with high tourism development claimed competent answers to new challenges and needed professional help in 
solving technical questions concerning tourism development in non-tourist regions [1]. One of the oldest methods of evaluating tourism factors is the method of overlaying maps with different tourism factors. This method evolved in USA, together with computer technology development and increase of digital cartography in the seventies [2]. For this purpose a special scale was developed to display different factors with a significant effect on tourist attractions in a certain area. These factors differed depending on two different types of tourism: touring and destination tourism.

In our case we are adding new contents to an existing geographical information system of the Slovenska Istra region [3], which are necessary for regional evaluation in view of tourism development (tourist capacities, sea-bed and shore grounds composition etc.). Individual regional factors, significant for efficient tourism product development were identified and recorded into maps which were then evaluated. By digitally overlaying - synthesizing evaluation maps of individual elements, significant for formation of specific tourism products - we obtained maps of regional suitability for individual tourism products. Based on these synthetic maps, decisions can be made on what areas of the region are best suited for specific tourism products.

\section{Method}

After all tourism resources are identified it is important to evaluate their usage value or their suitability for eventual tourism products. Based on these evaluations we can establish what areas in the region are best suited for individual tourism products.

When tourism products were first selected, we had to consider tourism resources of Slovenska Istra region, which include natural resources as well as social circumstances and general and tourism infrastructure. We also took into account the inquiry of an existing and potential tourism market, based upon modern marketing analyses and opinion polls in the region in question or similar regions worldwide.

Selection of suitable factors, which are important for specific tourism products, is of key importance to region evaluation for these products. For this factor selection, target groups (market segment) for the specific products in question were also taken into account.

To evaluate suitability of the region for specific tourism products and market segments (in brackets) we considered only the most important factors.

- Swimming and sunbathing (families, youth)

- The sun, the sea and entertainment (youth)

- Climatic or thermal health resorts by the coast (elders)

- Wellness centers and programs (managers, elders)

- Nautical tourism (sailors, sea-voyage fans)

- Diving and sea-bed observation (divers, diving and sea-life fans)

- Land sports (athletes on preparation, recreational sports fans)

- Water sports (athletes on preparation, recreational sports fans) 
- Golf (golf lovers, their friends and families)

- Natural science and environment education (specialists - researchers, school groups, nature lovers)

- Tourism on farms (families with little children, elders, nature loves)

- Discovery itineraries (culture and nature lovers, gastronomy fans, children, religious people)

- Congressional tourism (education participants, experts, scientists)

- Gaming tourism (gambling and entertainment lovers)

- Business tourism (businessmen)

- Travel tourism (youth, families, recreational visitors, shoppers)

Evaluation of the region's suitability for specific tourist products has been carried out with the help of a geographic information system (GIS) Idrisi [4]. Locations of different factors in the region (for instance: hotels) were implicated on individual layers or maps, giving us a computer processed map for each factor that is significant for at least one tourism product. These maps show us a layout of each factor in the region. To assess the suitability of the region for a specific tourism product, we then overlaid the maps with all the factors, significant for this product. The more factors appear in one specific area, the more suitable that area is for the tourism product in question. The evaluation maps for individual tourism products thus show what areas are best suited for each products development.

The presented model shows us which factors are momentarily significant for individual tourism products. There are two things we have to keep in mind:

- Usage value of tourism resources changes with regard to specific tourism product's demands

- Anthropogenic tourism resources can be recreated in certain areas, thereby changing the suitability level of these areas

Updating databases in an existing GIS is a quick way to get an up-to-date model. New factors can be added in a similar way if they appear or if they become significant for a certain tourism product. It is also possible to exclude factors of no more value or even add value to certain factors, should circumstances prove this a necessary action.

Individual factors were treated as equally important, because the literature we had gave us no basis to value different factors differently or to attribute different value to specific factors. The importance of one factor group (natural factors, general of tourism infrastructure) can nonetheless be higher in certain tourism products. In our case of evaluation this is showed by a larger number of factors in more important groups, while other - less significant or non-significant groups are represented by only a few factors or none at all. For instance: When we take into account the tourism product "swimming and sunbathing", natural factors are represented in larger numbers (duration of suitable seawater temperature, sea-bed composition, littoral ground composition, swimming water quality), followed by general infrastructure factor group (basic beach organization, traffic 
accessibility); while the tourism infrastructure factor group is the less significant group in this case.

An evaluation of suitability of Slovenska Istra for selected tourism products will be presented in the following chapter.

\section{Evaluating the Slovenska Istra region for selected tourism products}

\subsection{Swimming and sunbathing}

By the process of evaluation we came to the conclusion that this tourism product can make use of the beaches alongside the Slovenian coast where there are places with accommodation capabilities. The part of the coast that Luka Koper occupies was excluded.

The climate is fairly unified in the entire coastline region up to 200 or even $250 \mathrm{~m}$ height above sea level has a coastal climate that according to Köppen fits the Mediterranean climate criteria [5]. The only exceptions are lower valley parts that have temperature inversion. Sea temperature exceeds $18^{\circ} \mathrm{C}$ between 12th May and 7th October. Some cliff beaches with north-east or east position are not best suited for afternoon sunbathing as the sun sets some time earlier there (around $6 \mathrm{PM}$ ). Beaches differ in size as well as in shore and sea-bed ground composition (stone - mostly rocks, gravel, sand, slime or concrete beaches). Sand beaches with wooden piers are the most popular ones ("Adria" Ankaran, Health resort Krka Strunjan, central beach - Portorož). Swimming and sunbathing requires seawater quality, beach safety and quality beach services, with good environmental education and information. Considering these criteria some beaches stand out and received an international ecology mark Blue flag by the Foundation of European environmental education (FEEE). The following beaches gained the Blue flag in 2009: city beach Koper, Žusterna, St. Simon's bay in Izola, Health resort Krka in Strunjan and central beach in Portorož.

Communal services regularly clean up all the beaches in settlements (even the unregulated ones). Other unregulated beaches that are off-reach are being cleaned by a boat dispatched by the Service for coastal protection (SVOM) of the Ministry for environment and spatial planning in Koper. Some other important beaches are: "Adria" Ankaran, city beach Koper, Žusterna and St. Simon's bay. Different events (entertaining, cultural and sports) and other services (banks, cash machines, healthcare services, pharmacies and different stores) are condensed in these coastal settlements as well.

The GIS maps helped us choose the most appropriate places for individual tourism products. We should nonetheless mention that there are settlements with seaside view, reachable from the coastline by public transport within 30 minutes that belong in the second suitability group for swimming and sunbathing. Amongst these, the settlements with accommodation capabilities and minimum services level (a store, gas station, post office) are more suitable than others. Third suitability group may contain settlements, reachable by public transport within no more than 60 minutes. 


\subsection{Climatic and thermal health resorts by the coast}

The south-west orientated slopes of Ankaran, Strunjan and Portorož peninsulas, with good microclimate conditions, offer refreshing sea breeze in summer and safety from strong northeast winds in winter. These are also the sunniest areas in the region which is why these areas were the first tourist destinations in Slovenska Istra region. In times of Austrian-Hungarian government they built health resorts for children rehabilitation here - Seehospitzi, which then became climate health resorts. At Portorož the program now contains healing with salt water, salty marine mud - fango, derived from nearby saltpans and lately thermal water as well. In nearby parks, which are today highly valuable, Mediterranean and exotic trees sorts were carefully planted. Nowadays, there are two resorts which benefit from this historic climatic health resort renomé and beneficial microclimate effects. These are Mladinsko zdravilišče in letovišče Rdečega križa Slovenije (Youth's Red Cross Resort of Slovenia), and Health resort Strunjan. Terme Portorož recently obtained thermal health status.

\subsection{Wellness programs}

Wellness program services are the most asked after tourism services today. Some hotels, especially at Portorož have already organized these services while others have plans on doing so as well. Wellness centers include water parks or swimming pools with different attractions and water massages, physiotherapy services, saunas, fitness programs, massage programs, cosmetic saloons and antistress programs. Presently there are a few hotels that can offer services in this extent: Žusterna in Koper, Bernardin hotels, hotels LifeClass in Portorož. Many other hotels offer some of these services, usually saunas, pools without the additional attractions, fitness programs, sometimes even physiotherapy and water massages. Wellness centers with the entire service program are planned in Ankaran, Izola and Lucija. This form of tourist services also demands hiking and natural recreational possibilities, which is why some inland places out of immediate seaside proximity also come in question.

\subsection{Nautical tourism}

All three marinas (Koper, Izola and Lucia) offer quality services and environment, which is proved by the three "Blue flags" obtained by FEEE. Their joint capacity is 1.900 sea-berths and 200 shore-berths with 2.100 shoreberths in Yachting center Izola. Koper also has plans for an additional 700 berth marina. The three city harbors and central docks offer some short-term berths as well.

The region's traffic accessibility for boat owners is suitable. The highway connects our marinas with all the major central-European cities, which makes our marinas the quickest access to Adriatic Sea. Portorož has a small airport where smaller personal type of aircrafts can land. Upgrading the airport would give us possibilities of regional range air travel. The closest bigger airport with regular flights to European capitals is in Trieste, Italy $(50 \mathrm{~km})$ others are 
Ljubljana $(150 \mathrm{~km})$, Pula, Croatia $(120 \mathrm{~km})$ and Venice, Italy $(170 \mathrm{~km})$. These airports also have connection to New York three times a week. The weakest traffic point is railroad connection with inland regions. The railroad is overencumbered by cargo transportation from Luka Koper and thereby fails to meet passenger transportation demands. Shopping possibilities are vast. Koper has two large shopping centers. There are number of settlements in the region with gaming centers among which the largest one is in Portorož. Nature preservation is in enviable state. Sub-aquatic parks still need to be organized and natural reserves need to be promoted. Entertainment and cultural events in the region are numerous and diverse, as well as secondary services like equipment and vessel renting and servicing, spare parts sale, diving centers and schools etc. The largest international boat show in Adriatic is held at Portorož Marina every year as well as four other similar shows. In the autumn 2002 the Marina at Izola was the host of an international nautical exhibit "Izola 2002" and ever since become an annual event.

\subsection{Golf}

The golf course in Lipica is the closest to the Slovenska Istra region, but the leading tourism managers of Portorož believe it is too remote and with only nine holes it does not meet the international tournament standards. It may have a growing potential but that potential has not been put to use lately. For a quite a while managers have been pointing out that the region needs a good golf course to raise its tourism quality. They believe that such a course should be built near the main tourist destination - Portorož.

A special spatial evaluation of possible locations in the region has been carried out. One of the biggest obstacles in choosing out a surface of 60 hectares for the course is highly fragmented ownership of land. A proposition for the construction of the course in the lowest area of valley of Dragonja has been formed. This area lies under a settlement of Sečovlje and vis-à-vis the Portorož airport. Majority owners of these lands are almost exclusively the Piran municipality and the Agricultural lands and forest fund of Republic of Slovenia. There are small parts within private ownership only. Another, very common obstacle on this location though. It lies on an area that has the best quality rural grounds. Re-categorization has already been confirmed by the Ministry of agriculture, which believes that all the characteristics of a golf course allow immediate change of categorization back to rural use, should this demand show substantial. The Ministry also believes that a golf course will have positive effects on countryside development an agriculture development as well.

Similar strategic agreements, about the necessity of a golf course have been made by tourist development planners at Ankaran peninsula [6]. Assessment of spatial evaluations and additional studies of economic justification have to be carried out before we can come to a decision on a most suitable and attractive microlocation. Luka Koper with its partners supports the construction of a golf course on an "Ankaran bonifica", but the location has similar issues as the one near Sečovlje. It lies at the bottom of a valley and thereby lacks attractiveness. It actually has some unpleasant sights: Luka Koper's scattered cargo terminal and 
tanks for oil derivates under Sermin. The proposed location in Osapska dolina lies in a highly qualitative rural area as well.

Best golf course locations would definitely be a gazebo location on top of a ridge of on mildly inclined slopes with seaside view. Such a location would be one of the proposed complexes on Krog above Sečovlje, which fail through because of a denationalization demands. The most attractive golf courses worldwide are the ones that emphasize special local environmental characteristics. These conditions would be best represented in a location above Izola - the Baredi.

\subsection{Natural sciences and environmental education}

In the case of this tourist's product the countryside has advantage in tourist resources over urban and suburban areas. Another interesting fact is that almost every countryside settlement in the region has a certain appeal for tourists or can at least be used as an accommodation. We have to point out two especially attractive areas: "Nature park Dragonja" and "Regional park of Kras". We need to emphasize that the construction of a pathway network is at its beginnings (cycling and hiking path Porečanka, cycling path in Kras inland on Pregarska planota etc.). Tourist information centers at Ankaran and Šmarje represent an ideal basis for what an organized tourism should offer in terms of nature-science and environmental education programs.

\subsection{Farm tourism}

The network of farms and wineries organized alongside the Istrian wine road are of basic importance for development of quality countryside restaurants and accommodation facilities. This product has a strong link with the "Naturescience and environmental education" product, as both have the same suitability area and they supplement each other's content. Inland areas are also abundant with woods and preserved nature than seaside areas, which enables easy use of nature for recreational purposes. There are many cultural heritage objects present at inland areas as well, which need to be properly promoted. Local events have to be presented with a wholesome and professional approach but with no loss to local characteristics.

Tourist attraction development on countryside has many possibilities: hiking, cycling, horse-riding in an intact nature with a beautiful views, visiting various traditional events, discovering gastronomical and ethnological specialties, vast cultural heritage, narrow acropolis settlements, residing in pleasing accommodation facilities, built by typical Istrian architecture principle. Stirred up hilly and fertile Mediterranean landscapes are as beautiful as the well known Toscana or Corsica, but at this stage facilities and service cannot be compared to those regions. Wine roads and enogastronomy have a rich tradition in Slovenia [7]. 


\subsection{Congress tourism}

Capacities for congressional tourism are the most extensive in modern congress centers in Portorož (Bernardin, the Morje Hotels, Grand hotel Metropol), but almost every hotel in the region has at least one congress room. These facilities are often offered together with wellness centers and similar services, as congressional guests often need relaxation and recreation. These guests also go shopping very often and that is why we have to keep that service in mind when congressional tourism is in question. A lot of these guests do their shopping in two bigger shopping centers in Koper or at smaller ones located at Lucija, Izola and Koper as well; some even go shopping in nearby Italy.

\subsection{Gaming tourism}

The only gaming house with a state concession for big gaming houses in Slovenska Istra is the one in Portorož. Smaller ones in size and contents are in Žusterna, on a Slovenian-Italian boarder at Škofije, and at Vila Andor - Ankaran. The gaming house at the border crossing in Škofije is momentarily expanding its activities. Other gaming saloons in the region are of negligible importance as they only consist of a restaurant and a few slot machines. As was stated above, the traffic accessibility is fairly satisfactory and will only improve when the highway network is finished. There are Domestic and international airports nearby the closest at Portorož (in need of an upgrade), Trieste, Ljubljana and Pula. Numerous yacht owners in Slovene marinas are regular visitors to gaming houses. Accommodation capacities and restaurants of high quality, which are significant for gambling guests, are condensed in Portorož, but there are some in Koper and Izola as well.

\section{Conclusions}

Region evaluation showed that the coastline is best suitable for most tourist products that involve seaside holiday tourism. As this is the only region in Slovenia that has sea access, on account of its existing general and tourist infrastructure, has always been evolving intensively. Its mosaic and preserved Mediterranean cultural landscape is its main comparative advantage which will attract even more tourists when traffic and other infrastructures develop further more (Figure 1).

We established that the inland also has a great potential although at this stage it is still fairly unexploited. Comparative advantages of the inland are its pleasant and heterogeneous Mediterranean landscapes, preserved natural values, friendliness of the local inhabitants, rich and typical cultural heritage, Istrian culinary together with quality wine (with geographical origin) drinking culture etc. There used to be no tourist development within inland regions, so in turn there is small or even lacks of tourist infrastructure. With systematic tourist development of countryside areas we could implement new tourist infrastructure: such as management of reserved nature areas [8], accommodation capacities, 


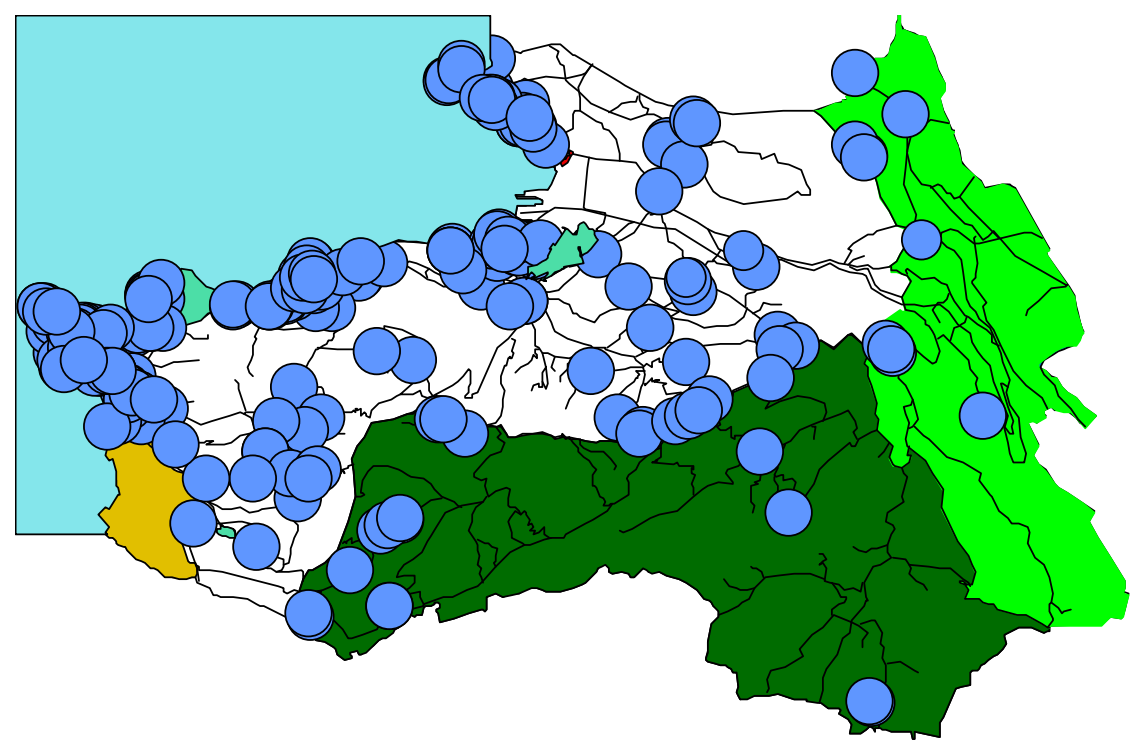

Legend:

\begin{tabular}{|c|}
\hline Natural park Dragonja (suggested) \\
\hline Kras regional park (suggested) \\
\hline Other natural values \\
\hline Other tourism resources \\
\hline Traffic network \\
\hline
\end{tabular}

Figure 1: Region evaluation for all the tourism products.

cycling, hiking, thematic and other paths for recreational purposes and other nature activities, sports courts and halls, golf courses and tourist informational centers. Different countryside events need to be organized and promoted, to present traditional activities and customs.

The results evaluated of tourist resources at Slovenska Istra showed that the region has various tourist resources which enable different tourist products to be formed in coastal settlements as well as in whole region area. The stated offers in this industry are suitable for a variety of tourist groups, subject to destinations, transition both in quality and price and for the whole region to develop suitable tourist applications, a fair amount of prudent investments will have to be made both in infrastructure and personnel. 


\section{References}

[1] Guigo, M., Davoine, P.A., Dubus, N., Guarnieri, F., Richard, B. \& Bailly, B, Gestion de l'environnement et systemes experts. Pariz: Masson, 1995.

[2] Gunn C.A., Tourism Planning. Levittown: Taylor \& Francis, 1994.

[3] Jurinčič, I., Regional evaluation of possible location for industrial location (with use of geographic information system), Ljubljana: Faculty of Arts, Department of Geography, 1993. (In Slovene).

[4] Eastman, J.R., Idrisi 32: Guide to GIS and Image Processing. Worcester: Clark University, 1999.

[5] Ogrin, D., The Climate of Slovene Istria. Koper: The Historical Society of Southern Primorska, 1995. (In Slovene).

[6] Jurinčič, I. (ed.), Ankaran peninsula - Future recreational zone between Italian Muggia/Milje and Slovene Koper/Capodistria. Koper: PHARE and Municipality of Koper, 2001.

[7] Jurinčič, I \& Bojnec, ŠS., Wine tourism development: The case of the wine district in Slovenia. Tourism 57, pp. 435-448, 2009.

[8] Jurinčič, I. \& Popič, A., Sustainable tourism development in protected areas on the pattern of Strunjan lanscape park. Varstvo narave 22, str. 177-192, 2009. 